\title{
Lodgepole Pine and White Spruce Establishment After Glyphosate and Fertilizer Treatments of Grassy Cutover Forest Land.
}

\author{
D. G. Blackmore ${ }^{1}$ and Wm. G. Corns ${ }^{2}$
}

\begin{abstract}
Perennial herbaceous vegetation, mainly marsh reed grass, (Calamagrostis canadensis (Michx) Beauv.), was sprayed with glyphosate on the day before planting one-year-old plugs of lodgepole pine (Pinus contorta Dougl. var. latifolia Engelm.) and white spruce (Picea glauca (Moench) Voss) on cutover forest land north of Edson, Alberta. Spraying at $4.5 \mathrm{~kg}$ ai/ha, included spot and strip applications in June 1976, compared with unsprayed scalps and controls. At the same time, all treatments were repeated plus a $9 \mathrm{~g}, 22-8-2$ fertilizer tablet for each seedling. Another experiment at the same site, begun on August 1,1976, compared scalp, unfertilized control and glyphosate strip treatments, followed by planting of pine seedlings the day after spraying $4.5 \mathrm{~kg}$ ai/ha glyphosate. An adjacent experiment, also commenced on August 1, included dosages of 1.1 to $5.6 \mathrm{~kg}$ ai/ha with planting of pine seedlings in 4.5 $\mathrm{kg} / \mathrm{ha}$ and in control plots in May 1977. August application of 2.2 $\mathrm{kg} / \mathrm{ha}$ provided excellent initial vegetation control, as effective as the larger amounts applied at that time, and was superior during the first 12 months to $4.5 \mathrm{~kg} / \mathrm{ha}$ applied in June. Twenty-six months after the spring planting new shoot growth of fertilized pine in the glyphosate strips was statistically significantly greater than that for all other treatments and growth in fertilized scalps was also very good. At the same time leader growth of spruce in fertilized scalps was significantly greater than that for other treatments but growth in glyphosate strips did not exceed that of unfertilized controls. Contrary to results of spring planting, there was marked injury and mortality of pine planted in August in glyphosate plots which had been sprayed on the preceding day. Seedlings planted in glyphosate-treated strips nine months after the August spraying exceeded the growth of control plants but not until the year after they were planted.
\end{abstract}

\section{Résumé}

On a arrosé la végétation herbacée vivace, surtout du foin bleu du Nord (Calamagrostis Canadensis (Michx.) Beauv.) avec du glyphosate le jour précédent la plantation en motte de pin lodgepole (Pinus contorta Loudon var. latifolia Engelm.) et d'épinette blanche (Picea glauca (Moench Voss) d'un an sur un terrain exploité au Nord d'Edson, Alberta. L'arrosage, à raison de $4.5 \mathrm{~kg}$ ai/ha, a été fait par point et par bande en juin 1976, en omettant de traiter pour fin de comparaison des places scarifiées et de contrôle. On a fait en même temps un deuxième traitement en ajoutant une pastille de fertilisant 9-g, 22-8-2 à chaque semis. Une autre expérience au même endroit, débutait le 1er août 1976 pour comparer les endroits scarifiés, les places de contrôle non fertilisées et les bandes traitées au glyphosate, suivie de la plantation de semis de pin le jour suivant l'arrosage de $4.5 \mathrm{~kg}$ ai/ha de glyphosate. Une expérience adjacente, entreprise le 1er août sur un site analogue, impliquait des doses de 1.1. à $5.6 \mathrm{~kg}$ ai/ha et la plantation de semis de pin dans les places de contrôle et celles arrosées à $4.5 \mathrm{~kg}$ ai $/ \mathrm{ha}$ en mai 1977. Le contrôle initial de la végétation fut excellent suite au traitement en août avec $2.2 \mathrm{~kg} / \mathrm{ha}$, aussi efficace que pour les traitements faits à la même époque avec de plus forts dosages, et meilleur au cours des 12 premiers mois à celui de $4.5 \mathrm{~kg} / \mathrm{ha}$ fait en juin. Vingt-six mois après la plantation printanière, la croissance des nouvelles pousses était sensiblement meilleure statistiquement que celle de tous les autres traitements et la croissance aux endroits scarifiés fertilisés était aussi très bonne. Également, la croissance de la pousse apicale des épinettes dans les endroits

\footnotetext{
${ }^{1}$ Former graduate student now with Alberta Energy and Natural Resources, Grande Prairie, Alberta T8V 2 L8

2 Professor of Plant Science, Department of Plant Science, The University of Alberta, Edmonton, Alberta T6G 2E3
}

scarifiés fertilisés était visiblement meilleure que celle pour les autres traitements quoique la croissance dans les bandes au glyphosate n'a pas été supérieure à celle dans les places de contrôle non fertilisées. A l'inverse des résultats obtenus par plantation printanière, le pin planté en août dans les places traitées au glyphosate le jour précédent montrait des signes évidents de blessures et de mortalité. La croissance des semis plantés dans les bandes traitées au glyphosate neuf mois après l'arrosage du mois d'août était meilleure que celle des plants de contrôle à compter de l'année suivant celle de leur plantation.

\section{Introduction}

Experiments reported in this paper were undertaken to determine effects of the herbicide glyphosate (n(phosphononethyl) glycine) on control of perennial grasses and on survival of conifer seedlings planted after spraying weedy cutover forest land in spring or mid-summer. Glyphosate has been used successfully as a translocated foliar spray on weedy perennial grass, followed several days later by cultivation of the treated area and seeding of farm crops (Valgardson and Corns 1974). Blackmore (1978) has reported studies on herbaceous vegetation control with herbicides, including glyphosate as an aid in conifer seedling establishment on uncultivated cutover forest land. Sutton (1978) has discussed the potential of glyphosate for forestry purposes and Noste and Phipps (1978) are among others who have worked with this herbicide in relation to various aspects of reforestation and forest release.

\section{Materials and Methods}

The experimental site was located in the foothills of Alberta, $41 \mathrm{~km} \mathrm{N.W}$. of Edson (SW 33-56-18, W5) adjacent to mature lodgepole pine forest on land clearcut in 1967 and drag scarified in 1970. The soil, classified in the Luvisolic order had developed on cobbly morainal deposits. The Alberta Department of Agriculture, Soil and Feed Testing Laboratory provided the following data for analyses representing the upper $15 \mathrm{~cm}$ of mineral soil: Available nutrients, kg/million kg soil-N:1 (low), P:18 (medium), K:103 (medium); $\mathrm{pH}: 4.9$; conductivity (mmhos):0,1, organic matter:low.

May-August precipitation was about $430 \mathrm{~mm}$ during the experiment. Records indicate that showers are frequent during the summer months in that foothills region.

The site had considerable variation in ground cover including deadfall, heavy grass usually on 8 to $15 \mathrm{~cm}$ of organic matter, alder (Alnus sp.) clumps, and patches of scattered forbs. Marsh reed grass was the dominant plant species. Fireweed (Epilobium angustifolium L.) was conspicuous.

\section{Experiment 1 - Spring Treatments}

The objective of this experiment was to apply enough herbicide for maximum weed control as soon as there was adequate grass foliage for spray treatment in the spring. In this way, estimation of greatest potential benefit of such treatments for outplanted conifer establishment and growth might be possible. 
A dosage of $4.5 \mathrm{~kg}$ ai/ha glyphosate in $325 \mathrm{~L} / \mathrm{ha}$ of spray mixture was used on the basis of work by Valgardson and Corns (1974) and on earlier preliminary trials on cutover land by Corns which indicated that this amount of chemical might be somewhat more that adequate for the present purpose. Scalping, fertilization and untreated controls were included to enable comparisons of their effects with those of the herbicide treatments.

Owing to variation in ground cover and existence of slash piles, it was considered impractical to arrange a formal randomization of the five replicates of 10 plants each for each of ten treatments. Accordingly, each treatment was in a single row. Each replicate of each treatment was established end to end, as a transect with plant positions staggered in order to avoid shrubs and bare spots which occurred randomly in the plot area. This procedure ensured a high degree of uniformity of planting spots in grass cover within and between treatments. All planting was done on June 16 , 1976, the day after glyphosate spray. The following treatments were about $1.5 \mathrm{~m}$ apart in a block averaging about $16 \mathrm{~m}$ wide and 50-60 $\mathrm{m}$ long.

1. Control (a): One year old seedlings of lodgepole pine about $10 \mathrm{~cm}$ tall, grown in Spencer-Lemaire fold-up containers were obtained from North Western Pulp and Power Co., Hinton and planted $1 \mathrm{~m}$ or more apart in undisturbed grass averaging about 385 stems $\mathrm{m}^{2}$ with foliage $15-43 \mathrm{~cm}$ tall. Fifty seedlings were planted in this and each of the remaining treatments. A dibble-type planting tool was used to make holes for insertion of the seedling plugs which were firmed in by the planter's heel.

2. Control (b): Seedlings were planted in dibble holes in 9.29 $\mathrm{dm}^{2}$ scalps to mineral soil, made with a hand mattock.

3. and 4. Glyphosate treated $28 \mathrm{~cm}$ and $56 \mathrm{~cm}$ diam. planting spots were sprayed and marked the day before planting the seedlings in the centre of the spots. The required amount of spray mixture was applied with a calibrated 10 $\mathrm{ml}$ continuous pipetting syringe fitted with s Spraying Systems Teejet Conejet type TX1 nozzle (Corns 1976). Spots were shielded by appropriate diameter metal cylinders during this operation.

5. Glyphosate treated strips $1.2 \mathrm{~m} \times 25.3 \mathrm{~m}$ were sprayed the day before planting the seedlings approximately 0.5 $\mathrm{m}$ apart along the central part of the strips. The strip treatment was done by spraying a $1.2 \mathrm{~m}$ wide swath with the exactly pre-measured volume of liquid for each strip, delivered from a portable compressed air tank-sprayer fitted with a small boom having 4 fan-type nozzles. Walking speed was regulated to enable application of all of the liquid during two complete passes along the plot length.

6. - 10. Treatments $1-5$ were repeated with the addition of one, $9 \mathrm{gm} 22-8-2$ slow release fertilizer tablet inserted at planting time within $2 \mathrm{~cm}$ of the upper $10 \mathrm{~cm}$ of each seedling plug.

An identical experiment with one year old white spruce plants was established adjacent to the pine plots.

Records consisted of total height measurements initially and in August of 1976, 1977 and 1978. Measurements of new shoot growth, as well as total height in 1978, were used in the final comparisons. In addition, periodic visual estimates of condition of each seedling were made on a scale of 0 to 4 : 0 -healthy, about $10 \%$ dead leaves on base of stem allowed; 1 -good, 0-25\% dead leaves; 2 -fair, $25-50 \%$; 3-poor, $50-99 \%$ dead leaves; 4-dead. Likewise, degree of vegetation control was rated as 0 -very poor, les than $25 \%$ reduction in cover density compared with adjacent untreated areas; 1-poor, 25-50\%; 2-fair, 50-75\%; 3-good, $75-99 \%$; 4-excellent, $100 \%$ control.

Data for 1977 were analysed by Duncan's New Multiple Range Test using five replicates of 10 seedlings each for each treatment row as noted above. Analyses based on the original total of 50 plants per treatment enabled a conser- vative estimate of total productivity differences. Final analyses in 1978 followed the same procedure for pine and included four replicates of 10 plants each for both species comprising the first 40 surviving plants in each treatment, in order also to consider potential differences unaffected by inclusion of missing plants. The few missing plants occurred randomly throughout the length of the plots.

\section{Experiment 2 - Mid-Summer Treatments}

The objective of this experiment was to determine if glyphosate treatment applied in August would have a different effect on weed control and pine survival and growth than the similar treatment applied in June. This experiment was located in the same cut block as Experiment 1. Grasses were up to $60 \mathrm{~cm}$ tall and somewhat denser than at the time of the June treatment in Experiment 1.

There were three replicates, each containing three randomized treatments with 50,14 month old Spencer-Lemaire pine seedling plugs per treatement.

1. Control - Seedlings planted in undisturbed soil.

2. Scalps - Seedlings planted in $9.29 \mathrm{dm}^{2}$ scalps to mineral soil.

3. Glyphosate treated strips $1.2 \mathrm{~m} \times 25.3 \mathrm{~m}$ sprayed with $4.5 \mathrm{~kg}$ ai/ha as in Experiment 1.

All plantings were done on August 2, 1976, the day after the glyphosate application, and records were taken as noted for Experiment 1. Experiment 3 - Mid-summer treatments with various dosages of glyphosate, and planting of pine seedlings in the $4.5 \mathrm{~kg} / \mathrm{ha}$ glyphosate strips in May of the next year.

The objectives of this experiment were to compare the effectiveness of glyphosate applied at various dosages in August, for control of herbaceous vegetation, and to determine the response of pine seedlings when planting was delayed until the year after the spray treatment.

Plots of Experiment 3 were near Experiment 2 in similar vegetation. There were three replicates each consisting of five strips $1.2 \mathrm{~m} \times 12.6 \mathrm{~m}$ sprayed on August 1, 1978 with glyphosate as before, at $1.1,2.2,3.4,4.5$ and $5.6 \mathrm{~kg}$ ai/ha in randomized blocks. There was approximately $1 \mathrm{~m}$ unsprayed material between strips. Some strips were not parallel to others. Approximately nine months later, on May 10, 1977, twenty, one-year-old lodgepole pine seedlings were planted in the $4.5 \mathrm{~kg} / \mathrm{ha}$ plots and in an untreated control plot for each replicate. As in Experiment 1, records for grass control, tree seedling condition and growth were taken during the two years after spraying. Analyses of variance were performed in 1977 and 1978, based on leader growth for all original plants and on means of surviving plants in each replicate.

\section{Results}

Herbaceous vegetation control-Spring Treatments (Experiment 1)

Two weeks after the glyphosate treatments $(4.5 \mathrm{~kg} / \mathrm{ha})$ the above ground control of grass was "excellent" (complete). Three months after treatment there was "fair" (65-75\%) vegetation control in the glyphosate spot treatments and "'good" (75-99\%) control in the strip plots and scalps. Fourteen months after application of the weed control treatments, control was "fair" (50-75\%) in the scalp and the spray treatments, except the $28-\mathrm{cm}$ spots where control was poor $(40-50 \%)$. Fireweed was the most abundant broad-leaved plant among the dominant grass re-invasion. Two years after spraying, all treatments except the strips were practically indistinguishable from the controls. Sprayed strips also were nearly completely overgrown but their vegetation was not yet as tall or as dense as the surrounding grass. General grass growth at this site was considerably more vigorous during 1978 than in 1976 and 1977. 


\section{Mid-Summer Treatments (Experiments 2 and 3)}

As in experiment one, initial control of vegetation in the glyphosate treated strips was excellent and 12 months later remained good. At the same time there was about $50 \%$ reinvasion of grasses and forbs in the scalps ("fair" control). The vegetation control from mid-summer treatments with glyphosate was superior to that achieved by the June treatment in Experiment 1.

In Experiment 3 which had dosages of 1.1 to $5.6 \mathrm{~kg}$ ai/ha glyphosate, all dosages above $1.1 \mathrm{~kg} / \mathrm{ha}$ maintained equally good control for one year after spraying. The $1.1 \mathrm{~kg} / \mathrm{ha}$ plots were rated as "fair" at that time. Two years after spraying, all strips had lost much of their superiority over those that received spring application of glyphosate. Grass reinvasion was extensive but still not as dense or as tall as in the controls. Fireweed was the main dicotyledonous species.

\section{Conifer Seedling Survival, Condition and Growth-Spring Treatments (Experiment 1)}

In all treatments the percentage survival after 14 months was greater than $94 \%$ for pine and between 82 and $98 \%$ for spruce, with most data in the upper part of this range. Seventy-six to $100 \%$ of the seedlings were in the healthygood $(0-1)$ condition. All pine plants in scalps and $96 \%$ of spruce plants in scalps were in this class. In August 1978, 26 months after planting, survival was still high for both species, $88-100 \%$ for pine and $82-96 \%$ for spruce (Table 1).

The height data for pine for 1978 (Table 1) show a numerical increase due to fertilizer, with all treatments, but the differences were significant only with scalps, glyphosate $56 \mathrm{~cm}$ diam. spots, and strip treatment. Likewise the results for 1977 showed corresponding benefits of fertilizer, significant also for the fertilized control in that year.

Scalping by itself did not improve seedling growth of pine compared with unscalped controls, but on fertilized scalps growth was higher than in fertilized or unfertilized controls.
Apparently the most beneficial treatments were the fertilized scalp and fertilized glyphosate strip treatment. Although mean total height of fertilized pine plants in uा glyphosate strip treatment was, as in 1977, not significantly greater than that of fertilized plants in scalps, the new leader growth in this strip in 1978 exceeded that of all other treatments. Analyses also on the basis of total seedlings planted showed the same relationships as in Table 1.

In 1977, the growth of spruce in fertilized control and fertilized scalp treatments exceeded the growth in glyphosate strips and untreated controls.

Results for spruce in 1978 (Table 1) also differed from those for pine. Height and new leader growth of fertilized spruce in glyphosate strips or spots showed no improvement over the corresponding measurements for plants in the fertilized unsprayed controls. There appeared to be a tendency for depression of spruce growth in the glyphosate strips.

Fertilizer caused no significant differences in height within treatments but the height of spruce in fertilized scalps significantly exceeded the height of plants in unfertilized controls.

New leader growth in 1978 was significantly different for fertilized and unfertilized controls and fertilized and unfertilized scalps. As with pine, leaders of plants in unfertilized scalps were not different from those of fertilized controls.

The leader length of spruce in fertilized scalps was greater that that for any other treatment.

\section{Mid-Summer Treatments (Experiment 2)}

Incipient injury to pine seedlings in glyphosate treated strips was evident within a month after spraying. After 12 months, the percentage survival of pine in such plots $(67 \%)$ was significantly lower than in the scalp (100\%) and control treatments $(94 \%)$. At that time, $90 \%$ of the plants in scalps were rated as healthy to good compared with $70 \%$ and $18 \%$ for those in the control and sprayed strips respectively.

Table 1. Data for lodgepole pine and white spruce seedlings in 1978,26 months after site preparation

\begin{tabular}{|c|c|c|c|c|c|c|}
\hline \multirow{2}{*}{ Treatments } & \multicolumn{2}{|c|}{ Survival \% } & \multicolumn{2}{|c|}{ Mean height } & \multicolumn{2}{|c|}{ New leader growth } \\
\hline & Pine & Spruce & Pine & Spruce & Pine & Spruce \\
\hline Control................... & 98 & 84 & $\begin{array}{l}(25.4 \mathrm{~cm})^{*} \\
100 \% \mathrm{c}-\mathrm{e}\end{array}$ & $\begin{array}{l}(13.6 \mathrm{~cm}) \\
100 \% \mathrm{bc}\end{array}$ & $\begin{array}{l}(9.3 \mathrm{~cm}) \\
100 \% \mathrm{c}-\mathrm{e}\end{array}$ & $\begin{array}{l}(4.1 \mathrm{~cm}) \\
100 \% \mathrm{de}\end{array}$ \\
\hline 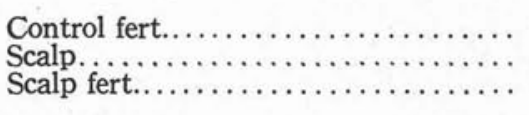 & $\begin{array}{l}96 \\
98 \\
98\end{array}$ & $\begin{array}{l}94 \\
96 \\
90\end{array}$ & $\begin{array}{r}104 \mathrm{~cd} \\
96 \mathrm{de} \\
124 \mathrm{ab}\end{array}$ & $\begin{array}{l}113 \mathrm{ab} \\
111 \mathrm{ab} \\
124 \mathrm{a}\end{array}$ & $\begin{array}{r}110 \mathrm{~cd} \\
95 \mathrm{de} \\
134 \mathrm{~b}\end{array}$ & $\begin{array}{l}136 \mathrm{bc} \\
131 \mathrm{bc} \\
175 \mathrm{a}\end{array}$ \\
\hline 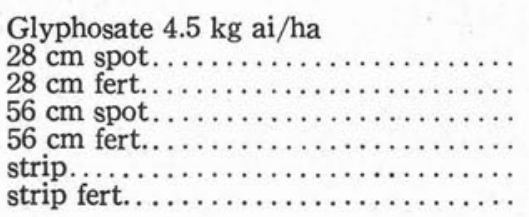 & $\begin{array}{r}94 \\
88 \\
96 \\
98 \\
100 \\
92\end{array}$ & $\begin{array}{l}90 \\
82 \\
82 \\
90 \\
96 \\
94\end{array}$ & $\begin{array}{l}86 \mathrm{e} \\
98 \mathrm{c}-\mathrm{e} \\
88 \mathrm{e} \\
112 \mathrm{bc} \\
106 \mathrm{~cd} \\
135 \mathrm{a}\end{array}$ & $\begin{array}{l}98 \mathrm{bc} \\
99 \mathrm{bc} \\
108 \mathrm{ab} \\
104 \mathrm{~b} \\
77.2 \mathrm{~d} \\
85 \mathrm{~cd}\end{array}$ & $\begin{array}{l}81 \mathrm{e} \\
95 \mathrm{de} \\
86 \mathrm{de} \\
120 \mathrm{bc} \\
120 \mathrm{bc} \\
169 \mathrm{a}\end{array}$ & $\begin{array}{l}121 \mathrm{~b}-\mathrm{d} \\
107 \mathrm{c}-\mathrm{e} \\
132 \mathrm{bc} \\
132 \mathrm{bc} \\
97 \mathrm{de} \\
91 \mathrm{e}\end{array}$ \\
\hline
\end{tabular}

*Mean measurements $\mathrm{cm} 40$ plants, expressed as percent of control. Means within columns followed by the same letter do not differ at the $5 \%$ leve using Duncan's new Multiple Range Test.

Table 2. Data for lodgepole pine seedlings in 1978, 14.5 months after planting in May 1977, after site preparation in August 1976

\begin{tabular}{|c|c|c|c|c|c|c|c|c|c|}
\hline \multirow[b]{2}{*}{ Treatments } & \multirow{2}{*}{$\frac{\text { Survival }}{\%}$} & \multicolumn{3}{|c|}{ Mean height $(\mathrm{cm})$} & \multirow[b]{2}{*}{$\%$} & \multicolumn{4}{|c|}{ New leader growth (cm) } \\
\hline & & $(\mathbf{T})^{\mathbf{a}}$ & $\%$ & (A) & & $(\mathbf{T})^{\mathrm{a}}$ & $\%$ & (A) & $\%$ \\
\hline 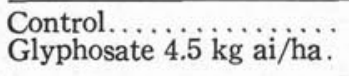 & $\begin{array}{r}87 \\
100\end{array}$ & $\begin{array}{l}11.8 \mathrm{~b}^{*} \\
16.2 \mathrm{a}\end{array}$ & $\begin{array}{l}100 \\
137\end{array}$ & $\begin{array}{l}13.7 \mathrm{a} \\
16.2 \mathrm{a}\end{array}$ & $\begin{array}{l}100 \\
116\end{array}$ & $\begin{array}{l}5.3 \mathrm{~b} \\
9.3 \mathrm{a}\end{array}$ & $\begin{array}{l}100 \\
175\end{array}$ & $\begin{array}{l}6.1 \mathrm{~b} \\
9.3 \mathrm{a}\end{array}$ & $\begin{array}{l}100 \\
152\end{array}$ \\
\hline
\end{tabular}

a(T) means for total seedlings plant (A) means for actual survivors.

*Means within columns followed by the same letter do not differ at the $5 \%$ level using Duncan's new Multiple Range Test. 
Mean height of pine in the glyphosate treated strips was significantly lower than seedling height in the scalp and control plots, viz. $60 \%$ of the $10.3 \mathrm{~cm}$ tall controls. Heights in scalps and controls were not significantly different.

Two years after treatments the above survival percentages had dropped for scalps, controls and glyphosate strips, to 95,84 and $54 \%$ survival, respectively. Because of the low survival of the pine in the glyphosate treatments, additional records for this experiment were not taken in 1978.

\section{Mid-Summer Treatment with Planting in the Next Spring (Experiment 3)}

In August 1977, one year after spraying and three months after planting, survival in the control and sprayed plots was 98 and $100 \%$ respectively. The condition of plants in the sprayed strips was at least as good as that of the controls. There was no significant difference in their leader lengths compared with controls during the year of planting. Fourteen and one-half months after delayed planting however, there was a pronounced increase in the shoot growth of the pine in the treated strips (Table 2).

\section{Discussion and Conclusions}

\section{Herbaceous Vegetation Control}

Mid-summer applications of glyphosate were more effective for perennial grass control than were spring applications. This was probably due to the presence of more shoots later in the season, which allowed greater herbicide translocation to rhizomes. Although a dosage of $2.5 \mathrm{~kg}$ ai/ha glyphosate applied in August was as effective as $4.5 \mathrm{~kg} / \mathrm{ha}$ applied in June, our experience with variation in vegetation response to glyphosate at different sites suggests that a dosage about 3 to $3.5 \mathrm{~kg} / \mathrm{ha}$ would likely be advisable as a general recommendation.

\section{Pine Seedling Survival and Growth}

The marked increase in pine leader growth in the fertilized glyphosate strip treatment in Experiment 1 in 1978 (Table 1) seems likely due to the fact that herbaceous reinvasion of such strips was still less dense than it was around the scalped and control areas, which had more luxuriant grass growth than in previous years. The same reason can be suggested for the superior growth in 1978 of the pine seedlings in glyphosate strips in Experiment 3 (Table 2) which had only become established in the preceding growing season.

Growth in fertilized scalps was prominent for both species and was superior in 1978 for pine in fertilized glyphoste strips. However, fertilizer had no appreciable effect in combination with glyphosate with spruce. Apparently, with spruce, glyphosate treatment had an inhibiting effect on growth promotion by the fertilizer.

We have no unequivocal explanation for the marked injury to pine seedlings planted on the day after spraying on August 1, in Experiment 2, in contrast with results for Experiment 1 , at the same site, after the same treatment, in June of the same year. Soil moisture was plentiful throughout both experiments. Moreover, there was glyphosate injury to both pine and spruce seedlings in a June experiment comparable to Experiment 1, near Stony Plain, Alberta, while growth improvement due to scalping with fertilization was, upon termination of the test in August 1977, at least as good as in Experiment 1 at Edson (Blackmore 1978). At Stony Plain, sandy soil characteristics may have delayed the inactivation of glyphosate. Our greenhouse studies with pine seedlings planted the day after glyphosate treatment of bare soil from different sites, with dosages as low as $2.2 \mathrm{~kg} / \mathrm{ha}$ (Blackmore and Corns 1977, Blackmore 1978) have provided added evidence of occurrence of injury in certain cases. In a more recent field study, over an 11-week period, (Corns 1978), there was visible injury to year old pine and spruce seedlings planted in sandy soil up to three days after spraying with $3.9 \mathrm{~kg}$ ai/ha glyphosate. Spruce appeared less affected than pine, at least over the short term of that trial.

Altogether, the results suggest the advisability of delayed planting. Spraying late in the growing season, followed by planting the next year, as in Experiment 3 , is one technique that permits planting operations early and safely, in the spring season, without having to wait for sufficient grass foliage to develop for an effective pre-planting spray treatment that same year. A potential alternative to the delay of planting after spraying, when both operations are planned for the same year, would be to scalp and plant immediately after spraying. This practice might reduce herbicide killing of the grass within the scalp but some herbicide translocation to invading rhizomes from surrounding treated plants could be expected. In any event, some weed growth in a scalp may be beneficial by reducing frost heaving of seedling conifers. Reduction or elimination of the surrounding cover facilitates light penetration and minimizes matted fallen grass smothering of the seedlings.

The advantages of combined scalping and fertilization evident in Experiment 1, without glyphosate treatment, warrant further attention, also in combination with herbicide treatments. Such combination with scalping would likely to most practical on sites having a heavy duff or peat cover above the mineral soil, a common occurrence in areas with a serious grass problem.

\section{Acknowledgements}

We gratefully acknowledge financial support from the Alberta Forest Development Research Trust, Monsanto Chemical Co., and The University of Alberta. Interested North Western Pulp and Power Co. officers at Hinton, Alberta provided the site and seedlings for this project. We also appreciate encouragement from the Alberta Forest Service to carry on the research. Drs. S. Zalik and P. Sharma of the Department of Plant Science and Mr. Brian Pinchbeck of Computing Services, The University of Alberta, provided very helpful advice and assistance with statistical analyses.

\section{References}

Blackmore, D., and Wm. G. Corns. 1977. Injury to lodgepole pine seedlings planted soon after glyphosate spraying of vegetation or bare soil. Res. Rep. Can. Weed Comm. West. Sect. 117-118.

Blackmore, D. G. 1978. Herbaceous vegetation control with herbicides during conifer seedling establishment for reforestation. M.Sc. Thesis, Dept. of Plant Science, University of Alberta.

Corns, Wm. G. 1976. An automatically refilling hand sprayer for applying small variable volumes of liquid. Res. Rep. Can. Weed Comm. West. Sect. 581.

Corns, Wm. G. 1978. Duration of glyphosate toxicity to lodgepole pine and white spruce seedlings planted in sprayed un cultivated soil. Res. Rep. Expert Comm. on Weeds, West. Can. 133-134.

Noste, Nonan V., and H. M. Phipps. 1978. Herbicide and container system effects on survival and early growth of conifers in northern Wisconsin. For. Chron. 54(4):209-212.

Sutton, R. F. 1978. Glyphosate herbicide: An assessment of forestry potential. For. Chron. 54:24-28.

Valgardson, D. R., and Wm. G. Corns. 1974. Influence of glyphosate and crop competition on quackgrass control and crop productivity. Can. J. Plant Sci. 54:789-793. 